\title{
Rigsdagspartiernes erklæring 29. juni 1949
}

En sidste parlamentarisk Sydslesvig-krise

\author{
af Johan Peter Noack
}

I oktober 1946 afviste Danmark, at Sydslesvig-spørgsmålet kunne løses gennem en folkeafstemning og en mulig grænseændring. En dansk-engelsk »rundbordskonference» i oktober 1948 nåede frem til, at det nu gjaldt om at sikre de dansksindede sydslesvigeres rettigheder som nationalt mindretal, dvs. uden grænserevision. Alligevel gjorde Knud Kristensen og dele af partiet Venstre derefter et aktivistisk fremstød - sydslesvigerne skulle have traktatfæstet muligheden for at udøve selvbestemmelsesretten. Det skabte en parlamentarisk krise i 1949. Episoden kom ikke til at bryde kontinuiteten i dansk Sydslesvig-politik, men den viser, hvor svært det også på dansk side var at indstille sig på den nationale afspænding, som fik udtryk i Kiel-erklæringen senere i 1949. Og den belyser, hvordan hele spørgsmålet var vavet sammen med andre sider af det parlamentariske liv i Danmark ved dette tidehverv. Rigsarkivar Johan Peter Noack skildrer forløbet og løfter dermed sløret for en del af en kommende større undersøgelse af det sydslesvigske spørgsmåls historie $\mathrm{i}$ årene 1948-1955.

Det dansk-tyske grænsespørgsmål efter 2. verdenskrig blev afgjort, da Danmark i oktober 1946 takkede nej. Socialdemokrater og Radikale vred da armen rundt på statsminister Knud Kristensen, der ledede Venstres mindretalsregering. Det lykkedes ham ganske vist et år efter at få sit valg på Sydslesvig, som han vandt, men udgangen blev alligevel en socialdemokratisk regering, som stilfærdigt stræbte efter at afdramatisere sagen. Det kom herunder den nye statsminister Hans Hedtoft til gavn, at dansk tilslutning til en vestlig forsvarsalliance pressede sig på. Da Venstre og Konservative var stærkt interesserede i denne kurs, kunne han på en rundbordskonference i det engelske udenrigsministerium i oktober 1948 binde dem til, at der nu burde forhandles om en mindretalspolitisk løsning på det sydslesvigske spørgsmål, dvs. en løsning uden grænserevision.

Efter måneders forberedelser fik briterne 29. marts 1949 de dansksindede sydslesvigere og den slesvig-holstenske landsregering til forhandlingsbordet $\mathrm{i}$ Kiel. Bestræbelserne her kronedes med held, for så vidt som det lykkedes at få landdagen til 26. september samme år at vedtage en erklæring, der garanterede mindretallets rettigheder. Men forud var gået en krise, hvor meget pegede på et brud. Da den tyske forbundsrepublik kun manglede enkelte vedtagelser, før 
den kunne springe ind på arenaen, havde landsregeringen en del at vinde, hvis den ikke sluttede forlig. Og de dansksindede sydslesvigere selv måtte indse, at gik de nu på overenskomst, satte de punktum for kampen for en grænseflytning. Det forte til indre brydninger, som resulterede i, at der 9. maj afgik andragender til den engelske og til den danske regering. Kravet heri var, at det nu skulle traktatfæstes, at sydslesvigerne havde ret til en senere folkeafstemning om landsdelens statslige tilhørsforhold. I realiteten lå forhandlingerne $\mathrm{i}$ Kiel derfor stille fra 4. maj til 16. juni. Netop i disse uger trak det op til en ny dansk parlamentarisk krise om Sydslesvig.

Som det sydslesvigske spørgsmål havde udviklet sig, var det ikke natur-

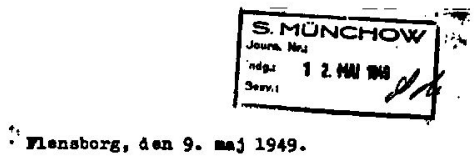

P11 den dencice regering.

O. Ia uger Fil Touttyokland efter elt at as an

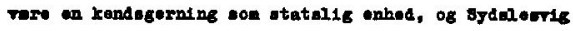

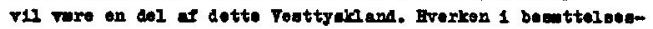
otatuten aler 1 den renttjabe forfatning er der faeteat

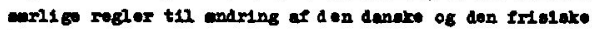

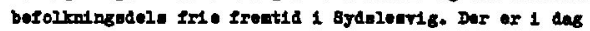

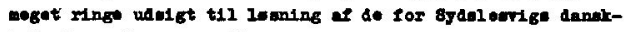
hed afgerende uporgambl.

T1 danke oydsl ourigere har fulgt don dangke rogeringe anximing rod eolv or ox for do allierede boradmagter at eremfore onbet on on folkeafatoming 1 gydalosvig, blia. 1 roxt memorandue at 27. jamuar 1947. Hen ror herrendeleer har hidtll voret uden robultat, ond 1kice ot svar or bloret givet, nasbe fordi otormabterne 1kice anoricender on gruppe tyake atets borgere von torhandingapartner.

Tor Irentidige arobne 11 derfor efter al sand-

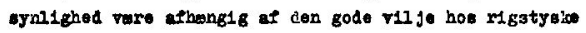
uydigheder og parlanentur - sactidig aed, at ror bjeastern fortast as huse hundrodtueinder af ereamide, we for staratedelen lkke har nalgt $t 11$ at kome endetoteds hent dase irenmsde kan efter sagena natur irke have lorstiel ab for rore traditioner, vor kal tur og vore ensker og er derfor alene ved deres nerverelse on ator fare for rort folkoliv.

gral kampen for denak og nord1 ak tenkegang fortenttes under disue var, er det eforende nodvendigt at have ot hab forade. T1 nener nu at whte herre par beaked af heniyn til den aydeleorf geke befolking.

Dor or 1 d we dage Ira sydslervigak Valgerforening rettet en horvendelse til de allisrode eagter, herunder Darmerk, on atkring af aelvbeatommelsouret for Bydelearis.
-2 -

Vi renter, at Danmark 1 den.ie stund over for hovedmagtarne Fil stotto dot sydoleavigale krar, 1 cat uindsto vod at ge ind for,

et det $i$ ot tilleg $t 11$ besettelsesstatuten for Vesttyabland og 1 den tyaxe fredatraxtat bestemen, at ien oydalesrigette betolkning oleel have ret til til diven fid at krwe on frl folkeafatemning blandt de hjeccehorenoe sydalegvigere of, bromilt vor ajemstavn gical hore til Danaark aller til pyskland, - uncer forudsutiling as, at Danmerl t1l den tid erciorer alg rede til at drage konselvengen af afsteminicen.

Derved 7111 e man alkre os retten til at rojge opargomelet t1l ain tid, uden at Dannark pa forininder " bundot. $8 \mathrm{~d}$ har $\boldsymbol{H}$ et crundiag at arbejde pa, ot hab om, at don deg han romme, da $\mathrm{v} 1$ med otemesedlen 1 hend selv ran Abne porten $t \pm 1$ Danmark. - Hene det, at Danmark

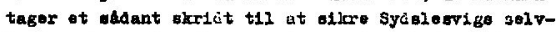
bestemeslaesret, 11 vere af storste betydning for rort hab t1] zemticen.

Dden on eddan stotte Ira Danmarir vil d ot se markt nd for ow. Blandt andet mitte $i \mathrm{~s} 8 \mathrm{rogne}$ oed on farstruende

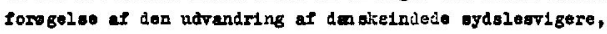
der allerede or begrndt ph rund af ce meget vanglesilge forhold 1 lendsdelen og ien vedkre politiake fremtid. Hvid gydeleavigerne - 1 mods thing til nordslegvigarne efter 1864 - at at uden his 121 freatiden, er ier grund t1l at frygte on endnu mere omfattende udvanaring and den atore ndvandring ofter $1864 \mathrm{fre}$ Nordsloovig, der eldrig har oploret on befolmingaforakyouning wom cen, Sydeloevig na er 1nde 1. Dette ville bringe aelve grundlaget for det denske folkallgo arbejde 1 sydeleavig 1 rare.

Hri. Danmarl ikite $\mathbf{1 l}$ give os háb til frentiden, wa v1 fralege os anstaret for on uavieling, der 1 cet lange 10b kan It elabneavangre talger bede for sydaleevig og for rordeleorig.

\section{Led erbodighed}

(Fiala Bagh interwon)

(3. 1unohow)

Den 9. maj 1949 rettede Sydslesvigsk Valgerforening et andragende til den engelske og danske regering $i$ et sidste forsog på at sikre sig adgang til en fremtidig folkeafstemning om landsdelens tilhersforhold. Samtidig sendte de to fremtradende sydslesvigere Niels Bogh Andersen og Samuel Münchow denne skrivelse til den danske regering $i$ samme sag. Arkivet ved Dansk Centralbibliotek, Niels Bagh Andersens arkiv P 282-6 og Samuel Münchows arkiv P 174. 
ligt, at det $\mathrm{i}$ forsommeren 1949 også i Danmark kom til en ny grænsepolitisk krise. Havde Venstre og Konservative fundet, at der kunne nås bedre resultater ved at distancere sig fra forliget fra oktober 1946, ville tidspunktet have været inde længe før. Senest i sommeren 1948 stod det indlysende klart, at en ny vesttysk stat var i støbeskeen. I stedet for at gøre et fremstød og forlange en løfteparagraf om en senere folkeafstemning lyste de to oppositionspartier stiltiende velsignelsen, da regeringen sammen med briterne begravede spørgsmålet om Sydslesvigs statslige tilhørsforhold. Det var i deres overordnede interesse at slutte op om Socialdemokratiet, mens det imod Kommunisterne og de Radikale førte Danmark ind i Nato. Selv om dette hensyn svækkedes, da optagelsen 24. marts 1949 blev vedtaget i Folketinget, ville det have været nærliggende, om forståelsen $i$ det mindste havde rakt noget længere. Det blev faktisk anført fra konservativ side. Nøglen til krisen er da også at finde $\mathrm{i}$ den indre uro, der satte sit præg på Venstre, mens arvefølgen efter Knud Kristensen skulle afgøres.

Forløbet rummer adskillige overraskelser. Venstre gjorde sig klar til at bruge Sydslesvigspørgsmålet til regeringsstorm, så snart alliancetilslutningen var vedtaget, men lod sig trods ivrig tilskyndelse fra Sydslesvigsk Udvalg overtale, da De Konservative argumenterede for en udsættelse. Da Folketinget før påske blev sendt på en godt to måneder lang ferie, skulle der have været fred og ingen fare. Efter nye urosignaler fra Sydslesvig i slutningen af april optrådte statsminister Hedtoft imidlertid så selvsikkert, at Venstres parlamentariske leder, Edvard Sørensen, gav provokerende igen. Skønt partiet fulgte denne linie op med et krav om en hurtig indkaldelse af tinget, da de sydslesvigske petitioner af 9. maj om at sikre afstemningsretten var fremkommet, bøjede det dog af for et konservativt forslag om, at den politiske opkogning blev holdt inden for Det udenrigspolitiske Nævn. Og selv om alt $i$ et sidste møde her 9. juni pegede mod et brud, affandt det sig med, at forhandlingerne fortsattes $i$ et udvalg, der først tog fat, da Folketinget igen mødtes 21.juni.

Det var ikke bare et udslag af almindelig politisk poker, at der først blev sluttet et forlig ved midnatstide 29. juni. Faktisk kom det bag på statsministeren selv, at Venstre til slut gav sig, fordi han forståeligt nok havde fået det fejlagtige indtryk, at krisen havde taget magten fra partiets strateger. Den udviklede da også en sådan egendynamik, at det blev af ikke ringe betydning, at forhandlingerne i Kiel var kommet $i$ gang igen 16. juni. Genoptagelsen hindrede, at statsministeren fik sit vigtigste argument for forlig slået af hænde. En vis rolle spillede det også, at sydslesvigerne selv ikke ville blotte sig for meget. Selv om de naturligvis måtte henvise til petitionerne af 9. maj, da oppositionen $\mathrm{i}$ den afgørende fase på ny bad om en tilkendegivelse, blev der svaret med en vaghed, der viste, hvor stærkt de frygtede konsekvenserne. 


\section{Knud Kristensen i opposition til sit eget parti}

For partiet Venstre havde Knud Kristensen og hans Sydslesvigpolitik ikke blot bragt fordele. Den tidligere statsminister udviklede sig efterhånden til en belastning. Selv om hans markante grænsepolitik havde bidraget til den store valgsejr i oktober 1947, udsprang der også forpligtelser, der indsnævrede spillerummet. Det kunne gøre Venstres ledende politikere irritable og nervøse. Da den radikale professor Aage Friis på et møde i Klubben af 1914 i København i november 1948 havde rost den sydslesvigske hovedtaler for at lade »det statspolitiske ligge«, for venstremanden Axel Kristensen op og bestred denne udlægning. Og da Knud Kristensens tidligere finansminister Thorkil Kristensen på samme møde havde givet et realistisk indtryk fra den dansk-engelske rundbordskonference, som havde fundet sted i London i dagene 18.23. oktober, men mærket, at aktivisterne dominerede stemningen, trak han noget $\mathrm{i}$ land og fremhæuede, at han selv var ophavsmand til den forrige regerings forsøg på at få »en sydslesvigsk paragraf $5 \ll .{ }^{1}$ Det var tydeligt nok, at partiets opslutning bag de tilstundende forhandlinger om en mindretalsordning hæmmedes af, at troværdigheden krævede en vis kontinuitet.

Det blev ikke lettere af, at den tidligere statsminister lidt ind i januar 1949 nedlagde sit folketingsmandat. Edvard Sørensen havde i november 1947 beholdt posten som partiets parlamentariske leder, og så længe Knud Kristensen var medlem af rigsdagsgruppen, havde ledelsen øjensynlig et vist held til at dæmpe ham og afstikke kursen selv. Det er næppe for meget sagt, at det også var en protest herimod, at han ikke ville indgå $i$ rundbordsdelegationen. I november kunne Aage Friis da også fra Christiansborg-snakken referere, at han "snart er helt færdig og træder ud af Rigsdagen«. Det var for den radikale historiker "stadig en gåde, at hans sunde jyske bondeforstand og tidligere mangel på interesse for slesvigske problemer ikke afholdt ham fra dårskaberne ${ }^{2}{ }^{2}$

Udmeldelsen kom med en harmdirrende erklæring i morgenbladene 12. januar. Mod rigsdagsflertallet rettede Knud Kristensen et skarpt angreb for ikke at følge bekendelsen til den nationale selvbestemmelse op: "... enhver indsats fra Rigsdagens side for at søge at sikre en sådan selvbestemmelsesret modsatte det sig på det bestemteste. " En folkeafstemning i Danmark havde man heller ikke villet give ham, og nu var resultatet, at man blot kunne henvise de danske sydslesvigere til "den tyske Kiel-regerings velvilje og nåde«. Når rigsdagsflertallet handlede mod »Danmarks livsinteresser«, ville han ikke længere være medlem. Dem kunne han bedre tjene udenfor, sluttede han sin erklæring. ${ }^{3}$

Næppe nogen fandt det helt rimeligt, at Knud Kristensen på denne måde 
gik sin vej og pudsede glorien. I sin kommentar fremhævede den konservative gruppeformand Ole Bjørn Kraft, at alt endnu ikke var tabt. Og Sydslesvigerne sad ikke alene over for landsregeringen i Kiel, indvendte han. Det samme gjorde Hans Hedtoft, der også understregede, at oppositionen havde været med i London. Stærkt sekunderet af Berlingske Tidende antydede den radikale leder Jørgen Jørgensen, at den tidligere statsminister ikke blot angreb folketingsflertallet, men også sit eget parti. ${ }^{4} \mathrm{Da}$ Grænsevagtens redaktør, dr. Vilh.la Cour, offentligt forfulgte hans personlige ansvar tilbage til svaret på det britiske tilbud $i$ efteråret 1946, svarede Knud Kristensen i et noget forurettet brev: "Mit ansvar over for 19. oktober [den såkaldte oktobernote, som indebar et dansk afslag på det engelske tilbud af 9. september 1946 om en snarlig folkeafstemning og påfølgende grænseregulering i Sydslesvig], og at Danmark måtte "nøjes« med den, består nemlig $\mathrm{i}$, at jeg rent faktisk ikke havde kræfter, magt til at nå videre, men både før og efter har jeg gjort, hvad jeg kunne for at forbedre den." Og da la Cour ikke lod ham slippe så let, havde han ikke andet at replicere, end at havde mindretallet haft flertallet i Folketinget, var der blevet ført en anden politik. At hans eget parti havde stået ham imod, mælede han ikke et ord om. ${ }^{5} \mathrm{Da}$ la Cour skrev sin vurdering til Grænsevagtens februarnummer, havde han da heller ikke sluppet Knud Kristensen af krogen: "Ingen siger, at han og hans partis - eller det konservative folkepartis medansvar er lige så stort som den daværende oppositions. Selvfølgelig ikke. Han kæmpede for en anden udformning af noten, så længe han mente kampen mulig. Men han bøjede sig omsider for at tjene den »enighed«, der ingen enighed var, ingen er og ingen kan blive. Så kan man diskutere, om »enigheden « var afkaldet værd. $\varkappa^{6}$

For Venstres rigsdagsgruppe blev det et problem, at den tidligere statsminister og siddende partiformand gik i opposition. At Knud Kristensen på sin måde faktisk mente sin trusel alvorligt, viste han, da han et par dage efter udtrædelsen på et offentligt møde angreb både den danske og den britiske regering og anbefalede at windanke sagen« for Frankrig og USA. Og i Århushallen agiterede han $\mathrm{i}$ begyndelsen af februar for en forsamling på 2.000 for ikke at give op, men finde et helt nyt grundlag for dansk Sydslesvigpolitik. ${ }^{7}$ Gruppeformanden Edvard Sørensen reagerede straks på mandatnedlæggelsen ved at identificere partiet med den udtrådtes linie. Det var ikke gået, som "Knud Kristensen og Venstre « ville. I hans handling lå "en protest mod regeringens politik «, som forhåbentlig ville få følger. ${ }^{8}$ Tonen var dæmpet, men forbeholdene manglede. Det ville ikke blive helt lige til for Thorkil Kristensen, der i januar var blevet udpeget til formand for partiets interne Sydslesvigudvalg. Da han havde været Venstres delegerede på rundbordskonferencen $\mathrm{i}$ London, havde han praktisk talt forpligtet sig på den mindretalspolitiske linie, 
som den socialdemokratiske regering tegnede. Posten som hans stedfortræder og den ledige plads i Det udenrigspolitiske Nævn blev besat med Jørgen Gram, Gabøl, der mest uforbeholdent havde bidraget til at føre Venstre frem på en aktivistisk kurs. Meget hurtigt markerede han sig og fik vedtaget en hilsen til professor Savory, der som parlamentsmedlem for Nordirland ved denne tid stillede en veritabel byge af spørgsmål i Underhuset. ${ }^{9}$ Et af dem gik på diskrimination $i$ tildeling af børnepenge efter en lov, vedtaget i nazistisk tid. Det føltes så pinligt, at udenrigsminister Ernest Bevin selv måtte overtage besvarelsen. Savory fremkaldte aldrig mere end små krusninger, der dog voldte betydelig irritation i Foreign Office. ${ }^{10}$ Der er ingen tvivl om, at hans operationer var tilrettelagt i samarbejde med Sydslesvigsk Udvalg, der i årene $1948 \mathrm{og}$ 1949 jæunligt havde pastor Hans Magle fra Tønder udsendt til London. " En hilsen til Savory, var således et buk for aktivisterne. Det hindrede dog ikke, at Venstre holdt sig til rundbordskursen, indtil det danske mindretal i Sydslesvig var parat til at forhandle $\mathrm{i}$ Kiel.

\section{Et mislykket afsæt}

For de første dage af april 1949 planlagde Venstre imidlertid et fremstød for at sikre selvbestemmelsesretten. Tidspunktet var egnet, fordi forhandlingerne i Kiel blev optaget 29. marts, og Danmark 4. april undertegnede NATO-traktaten. En måned tidligere havde Jørgen Gram og Edvard Sørensen rejst spørgsmålet i rigsdagsgruppen. ${ }^{12} \mathrm{Da}$ de umiddelbart efter kontaktede De Konservative, vinkede Ole Bjørn Kraft af. Tidspunktet var uegnet, sålænge der ikke var taget fat $\mathrm{i}$ Kiel, og alliancen endnu ikke $\mathrm{i}$ hus. En ny sondering efter månedens midte gav samme svar, selv om det stod klart, at De Konservative ikke kunne blive ved at holde igen. ${ }^{13}$ Ved månedens udgang nærmede tiden sig. Jørgen Jørgensen varslede 30 . marts i den radikale gruppe, at der ville komme en aktion fra de to oppositionspartier. ${ }^{14}$ Dagen efter fik Edvard Sørensen vedtaget, at Venstre skulle stile efter en særlig Sydslesvigdebat i folketinget 5. april. Det må have gjort et ikke ringe indtryk, at tillidsmændene på Sjælland og Bornholm ifølge Aksel Kristensen ventede det, da alle vidste, hvor stærkt Knud Kristensen stod blandt de jyske. Samme dag kaldte statsminister Hedtoft partiformændene til sig for at gøre dem klart, at han ikke ønskede en særlig Sydslesvigdebat. ${ }^{15}$

Først $\mathrm{i}$ et nyt partiformandsmøde 4. april gav Venstre efter for presset og frafaldt sit fremstød i denne omgang. Da partiet modsatte sig et konservativt ønske om, at aftalen med regeringen blev udmøntet $i$ en offentlig erklaring, er den kun bevaret $i$ et referat af Edvard Sørensens forelæggelse for Venstres 
hovedbestyrelse nogle dage senere. Herefter skulle Hedtoft til gengald have stillet i udsigt, at regeringen efter et resultat $i$ Kiel skulle indkalde partiformændene til nye forhandlinger, at der skulle rettes en ny henvendelse til de allierede besættelsesmagter, og at statsministeren ville gentage den erklæring, han 13. december 1945 havde fremsat i Folketinget. Edvard Sørensen forsvarede aftalen med, at ledende danske sydslesvigere indtrængende havde henstillet, at Venstre afstod fra et dagsordensforslag, der kunne føre til valg nu. I stedet ville de efter Kiel-forhandlingerne anmode regeringen om at søge selvbestemmelsesretten forankret. ${ }^{16}$ Under advarsler fra Thorkil Kristensen vedtog gruppen et par dage efter, at der i stedet skulle aktioneres på den økonomiske liberalisering. ${ }^{17}$

Der er næppe tvivl om, at det var De Konservative, der havde fået trukket Sydslesvig ud af stormlobet. Da det kom til afslutningsdebatten 7.-8. april, nægtede de da også $i$ det hele taget at følge Venstre. Under en pause ud på den sidste dags aften kunne den radikale Bertel Dahlgaard formulere en afværgedagsorden for regeringen på et tip om, at De Konservative ville undlade at stemme for Venstres forslag. ${ }^{18}$ Det holdt ganske rigtigt stik. Efter mødets genoptagelse begrundede Kraft partiets standpunkt med, at regeringen burde have fred til at gennemføre de forsvarslove, Nato medførte. ${ }^{19}$

Før regeringen således red stormen af, havde Sydslesvig under afslutningsdebatten fået sit. "Politisk klopfægteri« kaldte Grænsevagten det og konstaterede, at der ingen opmuntring var at hente for de dansksindede sydslesvigere. ${ }^{20}$ Indtrykket bekræftedes af, at regnen 7 . april om aftenen gjorde et fakkelbærende folketog til Christiansborg til en fuser. Det var arrangeret af Sydslesvigsk Udvalg, Slesvig-Ligaen, Dansk-Nordisk Ungdomsforbund og de københavnske sønderjyske foreninger. Mens næppe mere end 5-10.000 ventede udenfor, afviste statsministeren kravet om, at »den danske regering og rigsdag søger virkeliggjort sydslesvigernes nationale selvbestemmelsesret ${ }^{21}{ }^{21}$ Tilskyndet af Kraft og Thorkil Kristensen holdt Hedtoft næste formiddag sit løfte om at bekræfte den tilslutning til selvbestemmelsesretten, han havde fremsat i december 1945. Men det skete med den kommentar, at oktobernoten stadig var regeringens politik. Og forinden havde han i tilslutning til den radikale Bertel Dahlgaard understreget, hvor betydningsfulde forhandlingerne i Kiel var, ikke blot for mindretallet, men også for Danmarks forhold til det nye Tyskland. Det kan ikke undre, at statsministeren udtrykkeligt tog afstand fra selvbestemmelsesrettens sikring, som oppositionens ordførere troligt havde krævet gennemført. Det interessante er, at det foregik med drejninger, der antydede, at også de var ved at have fået nok. Kraft opblødte således kravet med et forslag om, at det kunne række med en almindelig sikring i den vesttyske forfatning af adgang til folkeafstemning for nationale mindretal. Det var ikke nødvendigt, 


\section{OPRAAB}

til alle

\section{Sydslesvig-Interesserede}

I Erkendelse af, at den Politik, der kom til Udtryk gennem den af de danske Partier skabte Oktobernote, uvagerlig er strandet, or det n $\phi d v e n d i g t$, at den danske Regering og Rigadag tager det sydslesvigsike Problem op til fornjet Droftelse for i den 11. Time at skabe den fornddne Forudseening for, at Sydslesvigerne, naar Tiden er inde, knn fan virkeliggjort den nationale Selvbestemmelsesret, som de danske demokratiske Partier i Teorien ex enige om.

Fot at bringe Regering og Rigsdag ef syligt Bevis pas, at dette Onske neeres I store Dele af dun danske Befolkning, of for samtidig at sende vore trofoste Landsmæend Syd for Grsensen en Hilsen og Opmuntring til fortsat Kamp afholdes

\section{Torsdag den 7. April et Folke- og Fakkeltog til Christiansborg,}

hvor Representanter for de deltagende Organisationer vil overrsekke Regering og Rigsdag en Resolution.

Folketoget samles fra K1, 19 paa Østervoldgade ved Garderkasemen og afgaar KI. 20, ledsaget af Falkelberere og 4 store Orkestre. Paa Slotspladsen vil der blive boldt 2 korte Talex og afsunget nationale Sange under Ledelse af et 80 Mands Orkester, indtil Deputationen vender tilbage.

Hvis vi foler, at Sydslesvigs Skrebne ligger os paa Sinde, kan vi ved denne

Med denne lobeseddel Lejlighed kun vare eet Sted - i Folketoget, enten som Deltager eller som Fatkelberer. Har De aldrig baaret en Fakkel for, saa er Lejligheden hex - jo flere vi moder, jo storre Vagt faar vor Henvendelse og Hilsen.

Tag Venner of Bekend te med! Vel mødt!

MØDEUDVALGET. 1949 for at stotte sydslesvigernes selvbestemmelsesret. Arkivet ved Dansk Centralbibliotek for Sydslesvig D c 21 .

P.S. Togets Rute: Gothergade-Kongens Nytorv-Holmens Kanal.

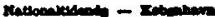

at den fik gyldighed specielt for sydslesvigerne. Og Erik Eriksen nævnte blot kravet for så at henvise til Venstres særlige Sydslesvigordfører. Da Thorkil Kristensen så fik ordet, opholdt han sig ganske vist længe ved den nationale selvbestemmelsesret. Nødvendigheden af at sikre den fastholdt han også. Men dertil beflittede han sig på at bruge sådanne datids- og førdatidsformer, at den opmærksomme tilhører måtte kunne forestille sig, hvordan kravet kunne gå i glemmebogen. ${ }^{22}$

Kort og godt, ledende danske politikere var for længst grundigt trætte af at snakke selvbestemmelse. De vidste godt, at tilslutningen til den danske bevægelse ville falde afgørende, mens man ventede på en folkeafstemning, der så 
aldrig kom. Det var i virkeligheden symptomatisk, at Venstre droppede Sydslesvig til fordel for den økonomiske liberalisering, da der skulle findes en dagsorden. Hedtoft og Bertel Dahlgaard rettede følgerigtigt blikket på Danmarks forhold til den kommende Forbundrepublik, mens Kraft og Thorkil Kristensen bad udgangsbønnen. Spørgsmålet var så blot, om den var for from til at nå ind til de vildfarne. I hvert fald den britiske ambassadør havde sine tvivl, da han kommenterede episoden: "Enkelt sagt har det danske parti i Sydslesvig det i sin magt at påvirke de to vigtigste oppositionspartier i Danmark og også den danske offentlige opinion $i$ almindelighed på et følelsesladet spørgsmål, på hvilket der altid er en mulighed for regeringens fald. ${ }^{23}$ Det skulle snart vise sig, at han delvis havde ret. Der var en sådan dynamik $i$ Venstre, at det var for tidligt for Hedtoft at ånde lettet op.

\section{Krisen bryder ud}

Trods tegn på uvejr åndede statsminister Hans Hedtoft godt og grundigt ud, da han holdt sin 1. maj tale. Han kendte da resolutionerne fra Sydslesvigsk Vælgerforenings landsmøde, der blev til petitionerne af 9. maj, men valgte at forme sine bemærkninger som et direkte modangreb på aktivisterne og deres politiske støtter i Danmark. Sydslesvigsk Udvalg havde netop holdt landsmøde i Odense, hvor den nye formand professor Hansen Larsen havde luftet den idé, at landsdelen burde indgå en mønt-og toldunion med Danmark. Og i en længere resolution hed det dramatisk, at det nu var $\mathrm{i}$ »12.time« at sikre selvbestemmelsesretten. I sit genmæle nøjedes Hedtoft da ikke blot med det gammelkendte arsenal af positive tilsagn og vægtede forbehold, men trak det svære skyts frem: "For klarheds skyld skal jeg gentage, at regeringen ikke agter at tage noget skridt, der kan blive forpligtende $i$ retning af at tilføre Danmark flere hundred tusinde tyskere. De aktivistiske kredse her i landet, der nu vender sig så voldsomt mod regeringen og rigsdagsflertallet, bør betænke, at de selv har et centnertungt ansvar, hvis der er skabt illusioner i Sydslesvig med hensyn til Danmarks holdning «. Og han sluttede sine bemærkninger med at advare mod "at lave rummel og partipolitisk agitation på denne sag«. På denne provokation gav Venstres Edvard Sørensen kontant igen, da han på et møde dagen efter $\mathrm{i}$ Aalborg krævede Rigsdagen indkaldt, så det kunne vedtages at holde en folkeafstemning i Danmark. Også Ole Bjørn Kraft tog til genmæle, nogle dage senere, vel at mærke uden direkte at støtte Edvard Sørensen. De Konservative var da også 4. maj i det konkrete kommet Venstre i forkøbet med en anmodning om, at Det udenrigspolitiske Nævn blev indkaldt. ${ }^{24}$ Meningen var klart nok at undgå et opgør for åbent tæppe i folketingssalen. Terrænet 
for en undvigende fægtning var således valgt, da de sydslesvigske petioner fremkom 9. maj.

Regeringen var opskræmt nok til, at udenrigsminister Gustav Rasmussen prøvede at hente skyts i London. I en samtale med viceudenrigsminister Lord Henderson 6. maj trak han frit perspektivet op. Den danske regering havde ikke taget imod det britiske tilbud om en folkeafstemning i september 1946. Den var heller ikke indstillet på at rejse spørgsmålet nu. Men dannelsen af en vesttysk stat havde bragt den under pres fra navnlig Venstre, der ville have en løfteparagraf om folkeafstemning optaget i forfatningen. Gustav Rasmussen sluttede med at spørge, om ikke den britiske regering ville være imod et sådant forslag. Hertil svarede Lord Henderson, wat hvis den danske regering besluttede at stille et formelt forslag af denne karakter, måtte Hans Majestæts regering overveje det. Som sin personlige mening følte han imidlertid, at det ville være et uheldigt tidspunkt for at genåbne dette spørgsmål, som den danske regering ikke havde gjort noget forsøg på at rejse, siden den i 1946 overlod det til sydslesvigerne selv at kræve retten til selvbestemmelse, hvis de valgte at gøre det. At rejse sagen nu ville fremkalde opposition fra tyskerne, og Hans Majestæts regering kunne ikke forfølge sagen ensidigt." Gustav Rasmussen takkede og gentog, at den danske regering ikke ville stille noget formelt forslag. ${ }^{25}$ Hendersons udtalelse var måske ikke helt, hvad udenrigsministeren var kommet efter, men den kunne vel bruges.

Også på anden vis forsøgte regeringen at gardere sig. Den indre danske krise afstedkom et crescendo $\mathrm{i}$ de danske bestræbelser på at få flygtningene østfra fjernet fra Sydslesvig. Alle forsøg havde været forgæves, men var troligt blevet gentaget. Udenrigsministeriet prøvede så tæt som muligt at følge, om briterne levede op til et halvt løfte, der var givet under rundbordskonferencen. Da der i april 1949 fremkom meddelelse om, at 300.000 flygtninge skulle overflyttes fra den britiske og den amerikanske zone til den franske, syntes for første gang en egentlig lettelse af trykket inden for rækkevidde. Det var næppe nogen tilfældighed, at Udenrigsministeriet netop 2. maj instruerede ambassadørerne i de tre allierede magters hovedstæder om at gøre opmærksom på, at Sydslesvig i særlig grad burde tilgodeses. Da der så blev modtaget underretning om, at kun 60.000 skulle flyttes fra hele Slesvig-Holsten, sendte ministeriet 13. juni en instruks om en ny henvendelse. Den blev 25. juni gentaget $i$ et brev til den amerikanske chargé d'affaires i København, og nogle dage senere fulgte en meddelelse om, at den aftrådte chef for militærmissionen $i$ Berlin, general Biering, skulle blive som en slags særlig kommissær til overvågning af flygtningesagen. ${ }^{26}$ Øjensynlig fandt ambassadør Henrik Kauffmann i Washington dette et for usmageligt pukkeri. I hvert fald tillod han sig i sin sidste note til den amerikanske regering blot at bede om, at der blev taget 
særlig hensyn til Slesvig-Holsten, ikke kun til Sydslesvig. Da han blev instrueret om at gøre skaden god, parerede han ordre, men bemærkede dog syrligt hjem, at forklaringen på afvigelsen lå i »koncipistens ønske om ikke at gentage i alt for høj grad «. ${ }^{27}$ Man må gå ud fra, at også andre end den højtanskrevne og selvstændige Washington-ambassadør inderst inde mente, at det tærede lovlig stærkt på Danmarks renommé, efterhånden som bataljerne på hjemmefronten udviklede sig.

Den undvigende fægtning stod i Det udenrigspolitiske Nævn 11. maj. Venstre var rykket sammen og angreb på den linie, gruppeformanden havde lagt med sin Aalborg-tale. Det hjalp ikke, at udenrigsministeren brugte hele det tilvejebragte arsenal. Forhandlingerne i Kiel skulle nok krones med en aftale, bedyrede Gustav Rasmussen og læste op af den sidste indberetning, hvor den danske forbindelseofficer i Sydslesvig, oberstløjtnant Lunding, bagatelliserede landsregeringens seneste manøvre. Der blev fra København giort alt for at tilgodese Sydslesvig, da flygtningenes fjernelse nu endelig så ud til at være kommet i skred. Og sidst men ikke mindst havde han i London konstateret, at det var for sent at rejse spørgsmålet om selvbestemmelsesrettens sikring. Briterne mente, at den sag "blev afgjort med det engelske memorandum af 9. september 1946 og det danske svar af 19. oktober s.å.« Det afholdt ikke Edvard Sørensen fra at begrunde og oplæse et medbragt brev, der blev overrakt til Vilhelm Buhl, da Hedtoft var sygemeldt. Dagen efter fremkom det i venstrepressen. ${ }^{28}$ Heri krævede Venstre Rigsdagen indkaldt. Vedtog den ikke at gå ind for sikringen, burde der holdes en folkeafstemning. Sigtede denne udvej på at få De Konservative til at springe på, havde Venstre imidlertid gjort regning uden vært. Ganske vist hældede Ole Bjørn Kraft i de fleste af sine vurderinger til Venstres side, men han ønskede en afgørelse udskudt, til regeringen havde fundet svar på en hel byge af vel forberedte spørgsmål. Efter at Jørgen Jørgensen og Buhl havde foreholdt Venstre, at initiativet var et brud på tilslutningen til sydslesvigernes forhandlingsgrundlag og forståelsen på partimødet 4. april, blev udgangen, at der skulle holdes et nyt møde..$^{29} \mathrm{I}$ tilslutning hertil havde partiformændene en drøftelse, hvor Kraft og Jørgen Jørgensen tilsluttede sig, at Rigsdagen skulle indkaldes, hvis der i næste nævnsmøde fremkom oplysninger, der kunne motivere det. ${ }^{30}$ Det tog Gustav Rasmussen henved tre uger at finde svarene til Kraft. Også De Konservative gjorde regeringen nok en tjeneste ved at tage sig god tid.

Det kunne i midten af maj 1949 se ud til, at et folketingsvalg lurede $i$ horisonten. Jørgen Jørgensen lod den radikale folketingsgruppe indkalde og fortalte her 16. maj, at han var »tilbøjelig til at tro, at løsningen må blive valg - det ville regeringen ikke være uinteresseret $i$ - idet man må gå ud fra, at Venstres krav om folkeafstemning ville få tilslutning fra Konservative og 
Retsforbundet«. Den tvivl, han havde tilbage, bundede i, at Venstre "måske ikke ville løbe risikoen for et valg på Sydslesvig . $^{31} \mathrm{I}$ den konservative rigsdagsgruppe steg presset da også på formanden, idet Aksel Møller i et møde 18. maj pressede på for at støtte kravet om Rigsdagens indkaldelse. Endnu holdt Ole Bjørn Kraft dog stand. Skulle han bekendtgøre dette, ville det bl.a. »føre til valg «. ${ }^{32}$ Helt til den dramatiske kulmination manøvrerede han da også intenst for at undgå et brud.

Udsigten til valg hvilede utvivlsomt også tungt på aktivisterne og de danske sydslesvigere selv. Sydslesvigsk Udvalg optrådte med en forbavsende sendrægtighed. Først ind i juni lanceredes den nye underskriftindsamling, som havde været under overvejelse siden januar. ${ }^{33}$ Ordlyden var tam. Underskriverne skulle blot opfordre »Regering og Rigsdag til af yderste evne at støtte de dansksindede sydslesvigeres naturlige selvbestemmelsesret «. Men selv om det lykkedes at få henved 800.000 til skrive under, blev aktionen en fuser. Adressen var først klar til aflevering $i$ april $1950 .{ }^{34}$ Grænseforeningens sendemandsmøde vedtog 28 . maj en mat resolution, der stillede flygtningespørgsmålet og frihedsrettighederne op først. Om det aktuelle spørgsmål hed det derefter: "... det er absolut påkrævet, at der nu skabes det fornødne stats- og folkeretslige grundlag for til sin tid at gøre den fra alle sider anerkendte naturlige selvbestemmelsesret gældende«. Det lød aktivistisk, men kunne fortolkes, så det dækkede en rent almen sikring, sådan som Ole Bjørn Kraft havde skitseret under Folketingets afslutningsdebat $\mathrm{i}$ april. I de følgende sætninger var denne udlægning faktisk mere end antydet. Da resolutionen var blevet til under stort bryderi i forretningsudvalget, blev der med held argumenteret for en uændret tilslutning fra hovedstyrelsen. ${ }^{35}$ Linien svarede da også godt nok til de forligsbestræbelser, formanden udfoldede. Til statsministeren sendte Holger Andersen 15. maj et længere eksposé, hvori han udførligt argumenterede for, at der selv i Tyskland ville være stemning for at knæsætte selvbestemmelsesretten som et generelt princip. På dette grundlag kunne der måske, henstillede han, udformes en erklæring, der løste den politiske krise. ${ }^{36}$

Efter opfordring fik Holger Andersen det også arrangeret, så Thorkil Kristensen og Ole Bjørn Kraft kunne drøfte situationen med ledende sydslesvigere. ${ }^{37} \mathrm{Om}$ ikke før så formentlig i forbindelse med årsmøderne i Sydslesvig 11. juni kom et sådant møde med Niels Bøgh Andersen, Samuel Münchow og Frants Thygesen i stand. Det var klart nok, at de måtte stå fast på petitionerne af 9. maj, men på den anden side udtale sig valent om, hvor langt oppositionen burde gå. Da Edvard Sørensen kort efter afkrævede dem et referat, svarede Münchow: "Det var resultatet af vor samtale, at vi ikke kan stå af på vor sidste bøn, men på den anden side ikke kan bedømme situationen godt nok til at sige, om der skal tages et valg eller ej, hvad der kan opnås inden et valg, 


\section{Til Beboerne i Hojrup og Arrild Sogne!}

Henvendelse:

I de kommende Uger vil De faa Besog anganende folgende

Til Regering og Rigsdagl

Undertegnede danske Stalsborgere over 23 Aar opforirer indtrangende Regering og Rigsday til af yderste Evne at stolle de dansksindede Sydslesvigeres Henvendelse. til vo 'e Allierede om en Sikring af de hjemmehorende Sydslesvigeres nationale Selvbestemmelsesrel.

Undertegnede vil indtrængende bede Dem om at skrive under paa denne Henvendelse, der i Princippet falder nøje sammen med den fæelles Udtalelse, som den danske Rigsdag fornylig har vedtaget, idet hele det danske Folk med Regering og Rigsdag i Spidsen staar samlet om Sydslesvigernes naturlige Selvbestemmelsesret. Poa Grund af dyrekøble Etfaringer for Nordslesvigs Vedkommende i Tiden tra 1864 til 1920 maa det imidlertid anses for bydende nødvendigt, at Selvbestemmelsesretien sikres traktatligt.

Niels Christensen, Fiskholm

P. Hansen. Fiskholm

Anders Moller, Hønning

Skovfoged Jensen, Arrild

N Bonderup,

Holger Johansen, Roost

Martin Pelz.

Margrethe Madsen, -
Nis Schmidt, Arnum

Alfred Christensen, -

Thomas Petersen, -

P. Haugaard,

Magnus Schmidt, -

Hans 'Thyssen,

Evald Moller,

Peter Schmidt. Højrup

Hans Bonde,

Den 18. april 1950 kunne Sydslesvigsk Udvalg aflevere 793.268 underskrifter til stette for Sydslesvigs selvbestemmelsesret til den danske statsminister og de fem gamle partiers ledere. Forud var gaet et omfattende indsamlingsarbejde. Denne annonce fra august 1949 belyser arbejdet $i$ Hojrup og Arrild sogne. Lignende henvendelser til de andre sogne $i$ Tonder Amt var indrykket $i$ de lokale blade $i$ månederne fra juli til september 1949. Arkivet ved Dansk Centralbibliotek for Sydslesvig. Knud Fanes arkiv P 261.

og hvor meget vi forbedrer situationen ved et valg « ${ }^{38}$ Det synes klart nok, at de er blevet spurgt, om de turde tage ansvaret for at kaste Danmark ud i et valg på Sydslesvig. Da de tydeligt nok ikke ville svare med et utvetydigt ja, fik Thorkil Kristenen og Kraft trods alt en tilkendegivelse, der kunne bruges. 


\section{Et blokeret forligsforsøg}

Selv om regeringen vel nok havde kunnet tage et valg, stilede statsministeren efter alt at dømme mod forlig. Ganske vist tegnede de økonomiske udsigter for første gang siden befrielsen forholdsvis lyst. Det var i foråret 1949, forsyningsminister Jens Otto Krag lod forstå, at Danmark lå »lunt i svinget«. Og vel havde det sikkerhedspolitiske problem fundet en løsning, der måtte påkalde respekt også blandt folk, der ikke var socialdemokratiske sympatisører. Men skulle oppositionen gøre livet for hedt, ville regeringen antagelig hellere tage et valg til efteråret. Og skulle det komme så vidt, måtte det hellere blive på øonomien end på det sydslesvigske spørgsmål.

Sådanne vurderinger synes at have ligget bag, da Hans Hedtoft endnu engang trak linien op. I sin tale på De samvirkende Fagforbunds generalforsamling 20. maj var det ham på den ene side tydeligt om at gøre, at det provokerende indtryk fra 1 . maj blev glattet ud. Han appellerede derfor indtrængende til alle partier om at bevare enigheden om det kompromis, som var nået $\mathrm{i}$ oktober 1946. Og han fremholdt, at »omsindelsen til danskheden" kunne være »dybt alvorligt ment«, skønt en egentlig afklaring måtte ligge længere ude i fremtiden. På den anden side lod han ingen tvivl tilbage om, at regeringen ville stå fast. Også Socialdemokratiet var for selvbestemmelsesretten. Selv om den ikke burde udøves nu, ville de demokratiske europæiske samarbejdsbestræbelser, som de fandt udtryk i Europarådet, sikre en afstemning på et senere tidspunkt, hvis sydslesvigerne holdt nok fast ved deres danske sindelag. Med sit krav om folkeafstemning havde Venstre brudt forståelsen fra rundbordskonferencen og drøftelserne om oplægget til forhandlingerne i Kiel. Og det kunne næppe realiseres, før den vesttyske grundlov trådte i kraft. Han måtte tage afstand fra "at spilde regeringens og Rigsdagens tid på et så løst grundlag«. Idet han henviste til en artikel i Vestkysten og til særlig Thorkil Kristensens synspunkter, appellerede han i virkeligheden til de stærke moderate kræfter i Venstre, der havde sat de hidtidige forlig igennem. ${ }^{39}$ Blandt de mange agitatoriske røster $\mathrm{i}$ disse uger fremkom da også enkelte, der kunne opfattes som en kvittering. Med støtte fra Fyns Tidende og Ringsted Folketidende talte således både Thorkil Kristensen og Aksel Kristensen mod et valg på Sydslesvig. ${ }^{40}$ Spørgsmålet var, om de havde styrke nok til at trænge igennem.

Umiddelbart tydede meget lidt på det, da partierne tog det næste livtag. I Det udenrigspolitiske Nævns møde 1. juni fremlagde Gustav Rasmussen de ønskede oplysninger og læste en erklæring op, som Hedtoft havde godkendt på forhånd: »Regeringens opfattelse er vedblivende den, at det ikke vil være i Danmarks interesse nu at stille eller støtte krav om, at der traktatmæssigt 
sikres sydslesvigerne adgang til at stemme sig til Danmark. $\kappa^{41}$ Edvard Sørensen gentog Venstres standpunkt: "... sagde Danmark nej til en afstemningsparagraf, ville det ... være dræbende for de dansksindede i Sydslesvig. « Kraft kørte vedblivende med to heste, idet han både støttede Venstre og talte for forlig med regeringen. Thorkil Kristensen støttede loyalt nok sin gruppeformand, men fik i samarbejde med Kraft understreget det nye problem i, om sydslesvigerne ville kunne undgå retsforfølgelse, når de arbejdede for selvbestemmelse. I et afsluttende indlæg greb statsministeren det som et punkt, der kunne indgå $i$ en kompromiserklæring sammen med arbejde for frihedsrettighederne og en praktisk indsats for bortflytning af flygtninge. Politikken var, som han havde trukket den op på DsF's kongres: "Regeringen ville ikke vige fra dette principielle standpunkt«. Kom det nu igen til "konflikt om Sydslesvig, ville et valg uanset udfaldet ikke give sydslesvigerne en hjælpende hånd, men ville tvært imod af den anden part kunne fortolkes som udtryk for, «at døren blev lukket i». Alle de i nævnet repræsenterede partier havde derfor et ansvar for, at en konflikt blev undgået.« Uden indsigelser kunne formanden, Julius Bomholt, herefter slutte med at beramme et nyt møde til 9. juni. ${ }^{42}$

Vel føjede der sig til udskydelsen andre tegn på, at et brud måske kunne undgås. Næste dag vedtog Venstres rigsdagsgruppe en erklæring, der fastholdt selvbestemmelsesrettens sikring. Det lød krigerisk, men Grænsevagten haftede sig ved, at kravet om folkeafstemning i den aktuelle situation ikke blev nævnt. ${ }^{43}$ Edvard Sørensen havde skrevet et udkast, som måtte erstattes af et nyt. ${ }^{44}$ Samme dag udsendte Kraft efter konferering med gruppebestyrelsen en udtalelse, der ridsede det humpende konservative standpunkt op. ${ }^{45}$ Da Jørgen Jørgensen nogle dage senere for den radikale gruppe vurderede situationen, mente han det wikke nødvendigt, at der kom et Sydslesvigvalg", og Bertel Dahlgaard supplerede allerede med overvejelser over, hvordan et efterårsvalg kunne undgås. ${ }^{46}$ I den socialdemokratiske gruppe skønnede formanden tilsvarende på grundlag af oppositionens erklæringer, at der måske »ikke længere er realitet $\mathrm{i}$ Venstres aktion, og at man er indstillet på forhandling « ${ }^{47}$ I hvert fald var der nu skaffet respit til, at det samarbejdende folkestyre tilbørligt kunne fejres på grundlovens hundredårsdag.

Alligevel tydede ikke meget under den næste konfrontation på, at parterne kunne finde hinanden. Før nævnsmødet 9. juni havde Hedtoft haft en udsending i Kiel, men det hjalp ikke stort, at Gustav Rasmussen kunne indlede med, at landsregeringen havde stillet et positivt resultat i udsigt. Edvard Sørensen insisterede på, at selvbestemmelsesrettens sikring blev taget med ud over de tre punkter, Hedtoft 1.juni havde skitseret som grundlag for en erklæring. Da Kraft derpå foreslog, at der blev nedsat et snævrere forhandlingsudvalg, blev resten af mødet til en diskussion af proceduren. Imod alle 
andre partier fremførte Edvard Sørensen, at et forlig om Hedtofts tre punkter kunne få værdi i sig selv. Viste det sig så, at selvbestemmelsens sikring frembød uoverstigelige vanskeligheder, kunne parterne på dette punkt være frit stillet. $\mathrm{Da}$ opgøret var nået hertil, desavouerede Thorkil Kristensen sin gruppeformand. Det førte kun til, at tidligere forsvarsminister Harald Petersen desto kraftigere rykkede ham til undsætning: "Man kunne lige så godt gøre sig klart, at Venstre havde taget sit standpunkt, nemlig at stille sig bag sydslesvigernes henvendelse. Havde regeringen taget det modsatte standpunkt, så taleren ikke, hvorledes der kunne komme noget ud af drøftelserne i udvalget, thi det var et meget stort spørgsmål, om det havde nogen værdi at få en udtalelse alene om de tre punkter.« I tillid til denne tiltrængte håndsrækning accepterede Edvard Sørensen udvalget. Drøftelser skulle først begynde, når Folketinget igen 21. juni blev samlet ${ }^{48}$ Det skete efter radikalt og konservativt ønske, imod Venstre, som ønskede dem indledt straks. ${ }^{49}$ Det måtte virke overraskende, at Harald Petersen rykkede ud på dette hårde standpunkt. Mens Knud Kristensen var statsminister, havde han hørt til den gruppe, som stædigt stilede mod forlig i Sydslesvigpolitikken. Der er næppe tvivl om, at den tidligere partisekretær nu så sig nødsaget til at sætte partiets enhed i højsædet. Spørgsmålet var så, hvor langt han kunne føle sig tvunget til at gå.

\section{Mod brud}

Da udvalgsdrøftelserne kom i gang, viste regeringen sin villighed til at strække sig. Det var dog kun på alle andre punkter end modstanden mod sikringen af en fremtidig folkeafstemning. I det første møde 21.juni fremlagde Gustav Rasmussen et udkast til en fælleserklæring, hvori det også hed, at ingen på grund af sit arbejde for selvbestemmelsesretten skulle kunne udsættes for

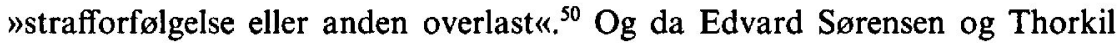
Kristensen for Venstre ville have mindretalsrettighederne optaget $i$ en tyṣk fredstraktat, erklærede Hedtoft sig parat til at støtte et sådant krav.$^{51}$ Det var dog ikke nok. På et nyt møde 23. juni forlangte Edvard Sørensen øjensynligt, at Danmark i en note til England skulle rejse spørgsmålet om selvbestemmelsesrettens sikring. Det blev derpå aftalt, at regeringen og Venstre skulle fremlægge hver deres afklarede forslag, når forhandlerne om aftenen tirsdag 28 . juni igen trådte sammen. Det var Hedtofts vurdering, at Venstre herefter ville gøre meget for at undgå et brud. Det byggede han navnlig på, at Thorkil Kristensen havde taget "definitivt og utvetydigt afstand fra Ejderpolitikken «, forstået på den måde, at »kun sogne med dansk flertal til sin tid skulle tilbage«. Statsministeren skønnede derfor, at en fløj omkring den tidligere finansminister 
ikke ønskede valg på Sydslesvig. ${ }^{52}$ Da De Konservative arbejdede for forlig, men næppe kunne gå alene, måtte nøglen ligge hos Venstre.

Afklaringen i Venstre blev yderst besværlig. Allerede i et gruppemøde 10. juni havde Aksel Kristensen beklaget, at det kunne komme til valg på Sydslesvig. Hertil replicerede Harald Petersen, at partiet ikke kunne frafalde sikringen af selvbestemmelsesretten. Da drøftelserne 22. juni blev genoptaget, bekræftede gruppen, at forhandlerne skulle stå fast. Skønt Erik Eriksen nu støttede Aksel Kristensens uvilje mod valg, stod Thorkil Kristensen isoleret over for den falanks, som Harald Petersen og Henrik Hauch mobiliserede bag formanden. Det kom her til et bittert opgør, da Edvard Sørensen beklagede, at Thorkil Kristensen havde inddraget sydslesvigerne i den politiske strid i Danmark. For at underbygge sit standpunkt læste han op af de breve, han havde rekvireret fra Flensborg. Da et redaktionsudvalg 24. juni forelagde gruppen sine udkast til den skriftlige fastlæggelse, Hedtoft havde bedt om, stod Thorkil Kristensen og Aksel Kristensen ikke uventet alene med hver sit forslag, hvori der til en fælleserklæring var føjet et særstandpunkt for Venstre. En trusel om at udtræde af forhandlingsudvalget fandt Thorkil Kristensen øjensynlig endnu ikke tiden inde til at effektuere. ${ }^{53}$

For at cementere det faste standpunkt var Venstres hovedbestyrelse indkaldt til morgenmøde 28. juni. Den fik her forelagt et forslag til erklæring, hvis kerne lød: »Regeringen vil derfor under de internationale forhandlinger om ordningen af Vesttysklands forhold, derunder forhandlingerne om fredstraktaten, tilstræbe en ordning, der sikrer muligheden for et sydslesvigsk initiativ til udøvelse af selvbestemmelsesretten med bevarelse af Danmarks ret til til den tid at tage stilling til sagen, og som tillige skaber baggrund for international forståelse af Danmarks særlige ønsker og interesser med henblik på løsningen af det sydslesvigske spørgsmål.« Edvard Sørensen fik på mødet den opbakning fra Knud Kristensen, han havde regnet med. Og med tilslutning fra redaktør Quist og Henrik Hauch begrundede Harald Petersen fastheden med, at det ikke gik "at have et standpunkt til vinduspynt og et andet i praktisk politik «. ${ }^{54}$ Efter en afbrydelse, hvor rigsdagsgruppen gav sin godkendelse, blev erklæringsforslaget vedtaget enstemmigt af hovedbestyrelsen..$^{5 s}$

På det afgørende punkt havde partierne knap nok nærmet sig hinanden, da forhandlerne 28. juni om eftermiddagen igen satte sig til bordet. Over for Venstres forslag havde regeringen flere dage før udsendt et udkast, hvor Hedtofts tilsagn om at arbejde for mindretalsrettighedernes optagelse i en tysk fredstraktat var indføjet. ${ }^{56} \mathrm{Da}$ de øvrige opfattede Venstres udspil som »kravet om en paragraf 5 «, der kun fremstod i »let kamufleret form «, så det ud til, at en folketingsdebat med dertil hørende dagsorden ikke ville kunne undgås. Med tilslutning fra alle andre end Venstres forhandlere foreslog da den radikale 
Jørgen Jørgensen, at fremsættelsen af en erklæring blev udsat, til den ikke længere kunne forstyrre forhandlingerne i Kiel. ${ }^{57}$ Samme dags aften færdiggiorde Udenrigsministeriet en så lydende pressemeddelelse. ${ }^{58} \mathrm{Da}$ statsministeren næste formiddag gav den socialdemokratiske rigsdagsgruppe sin vurdering, understregede han, hvor uigennemskuelig Venstres stilling forekom. Regeringen ville ikke lade sig rokke. Det kunne »blive en overraskelsernes dag « ${ }^{59}$

\section{Overrumpling}

Overraskende vendinger bragte forhandlingerne 29. juni flere af, men til syvende og sidst ikke som Hedtoft havde ventet dem. Længe så det dog ud til at trakke op til det valg, han havde villet varsle. Et formiddagsmøde i Venstres gruppe mundede ud $i$ en afstemning, der gav et overvældende flertal for at afvise en udsættelse. Det hjalp ikke, at Thorkil Kristensen kunne henvise til, at Bøgh Andersen i en ny drøftelse med en hidkaldt sydslesvigsk delegation aftenen før havde frarådet et brud. ${ }^{60} \mathrm{Da}$ forhandlingsudvalget efter middag trådte sammen, tegnede der sig derpå et flertal for en erklæring uden om Venstre. Spørgsmålet blev da, om partiet i denne situation ville give afkald på folketingsdebat og dagsordensforslag. Hedtoft var øjensynlig rede til på enkelte punkter at komme De Konservative i møde, men forlangte nu en afklaring samme dag. ${ }^{61}$ I et gruppemøde vedtog Venstre med stort flertal at sige nej til det ønskede afkald. Og Thorkil Kristensens senest i formiddagsmødet gentagne trusel om at træde ud af forhandlingsudvalget blev nu taget til efterretning, idet gruppen erstattede ham med Harald Petersen, der fik 34 stemmer mod 22 på Aksel Kristensen. ${ }^{62}$ Da Venstres forhandlere herefter ind under aften insisterede på en dagsordensdebat i påkommende tilfælde, sprang De Konservative fra tilsagnet om udsattelse. Der var herefter ingen anden udvej end at fortsætte drøftelserne om en kompromiserklæring. Til det formål blev der nedsat et snævrere redaktionsudvalg. ${ }^{63}$ På dette tidspunkt syntes alt at pege på et brud.

I lobet af aftenen overrumplede Harald Petersen imidlertid alt og alle ved at indgå et forlig. Venstre tilsluttede sig en erklæring, der ikke krævede selvbestemmelsesretten sikret. Til gengæld affandt de øvrige partier sig med, at det udsendte sin egen kortfattede erklæring herom. I den socialdemokratiske folketingsgruppe var der nærmest skuffelse. Gustav Pedersen kommenterede forliget: "... lige så stærkt vi havde stået, hvis Venstre havde sprængt forhandlingerne, lige så uheldigt ville det være at gå til valg ved at nægte en eller anden passus $\mathrm{i}$ erklæringen." $\mathrm{Og}$ statsministeren havde i Harald Petersens tilsynekomst set et tegn på, "at det - på saglig vis - ville have været let, at få 
forhandlingerne sprængt, men det gik lige omvendt $«{ }^{64}$ Da Harald Petersen anbefalede, at Venstres godtog forliget, blev det nærmest med beklagelse taget til efterretning. Edvard Sørensen meddelte opgivende, at han ikke ville påvirke gruppens stilling. ${ }^{65}$ Det var for så vidt antiklimaks. Men lige så udpræget denne stemning herskede i Venstre og Socialdemokratiet, lige så lettet må De Radikale og ikke mindst De Konservative have følt sig.

Kun en mand med Harald Petersens ry for tro tjeneste i partiet kunne satte sig ud over rigsdagsgruppens og hovedbestyrelsens dugfriske vedtagelser. Næppe nogen kan have fundet på at skyde ham andet i skoene end de meget stærke grunde, han må have haft. Han var formentlig selv blevet overrumplet, da de sydslesvigske petitioner 9. maj så godt som forhindrede, at rigsdagsgruppen fik dæmpet sin formand ned efter den kraftige reaktion på statsministerens 1. majtale. Mens han ventede på, at en passende lejlighed skulle melde sig, afslørede Thorkil Kristensen i Det udenrigspolitiske Nævn faren for et skisma. I denne situation var det forbundet med den største fare at lade Edvard Sørensen i stikken, særlig da når Knud Kristensen stadig havde posten som partiformand. Harald Petersen så derfor ingen anden udvej end selv at bidrage til den fasthed, som Venstres ansigt udadtil da også kaldte på. Aksel Kristensen og Erik Eriksen kunne han efter alt at dømme føle sig sikker på, og risikoen var til at overskue, hvis Thorkil Kristensen skulle gå enegang. Men da han først havde reddet partiets enhed, kunne han fra den nøgleposition, han kom til at indtage, sent, men ikke for sent, lade sine egne vurderinger slå igennem. Partiet havde næppe væsentlig mere at vinde på et nyt Sydslesvigvalg. Tværtimod ville det for lang tid forgifte forholdet til De Konservative. Efter alt at dømme var det de afgørende momenter. Selv om det næppe var fuldt forudset, banede Harald Petersen 29. juni om aftenen vejen for den regering, Erik Eriksen godt et år senere dannede i samarbejde med De Konservative. Ganske vist blev Edvard Sørensen i september valgt til ny partiformand efter Knud Kristensen, men både han og Thorkil Kristensen havde afsløret, at de ikke bar marskalstaven $\mathrm{i}$ tornystret. For så vidt denne fortolkning holder stik, viser den parlamentariske krise i forsommeren 1949, at et åbent grænsespørgsmål ikke længere blot var Socialdemokratiet i vejen, men også hindrede udfoldelsen af det borgerlige alternativ til det.

\section{Slutning}

Forliget skabte et nyt grundlag for dansk Sydslesvigpolitik. I erklæringen af 29. juni fra Socialdemokratiet, Venstre, Det konservative folkeparti, Det radikale Venstre og Retsforbundet lykkedes det for regeringen at få understreget 
kontinuiteten: som fremhævet i de danske memoranda af 19. oktober $1946 \mathrm{og}$ 31. januar 1947 var grundlaget den nationale selvbestemmelsesret. Til gengald fik Venstre anbragt en dulgt hentydning til Sydslesvigs administrative adskillelse fra Holsten og en forsikring om, at Danmark ville støtte den frie »kulturkamp«, under hvilken »landsdelens skæbne« ville blive afgjort. På det springende punkt lykkedes det ikke Venstre at trænge igennem. Kernen lød: "Det er en konsekvens af selvbestemmelsesretten, at en befolkning $i$ et nationalt blandet område har ret til med alle demokratiske midler at virke for at få adgang til at udøve den, og at følgelig ingen af den grund skal kunne udsættes for strafforfølgning eller anden overlast. Vi erklærer at ville støtte en politik, der tilstræber $\mathrm{i}$ internationale overenskomster at opnå dette anerkendt for de dansksindede sydslesvigere. $\ll^{66}$ Dermed var intet tilsagn givet om støtte til at få en fremtidig folkeafstemning sikret på den ene eller den anden vis. Da regeringen i løbet af juli notificerede stormagterne, blev erklæringen det officielle grundlag for Danmarks Sydslesvigpolitik. ${ }^{67}$

Skønt partiernes erklæring af 29. juni 1949 formelt bevarede sin gyldighed ud over København-Bonn erklæringerne i 1955, fik den næppe nogen reel betydning de følgende år. Det er også værd at understrege, at den strid, der gik forud, for så vidt var uvirkelig, som alle ledende politikere nord og syd for grænsen var klar over, at selv en sikring af selvbestemmelsesrettens udøvelse nogle år ude i fremtiden ville komme så sent, at der næppe længere ville være dansk flertal i Sydslesvig. I hvert fald hvis der ses bort fra den eventualitet, at mindretallet bekvemmede sig til at indsnævre grænseflytningskravet til Flensborg by med nærmeste omegn. Sin egentlige betydning fik erklæringen derfor i den aktuelle situation. Den tilkendegav klart, at de danske sydslesvigere ikke skulle håbe på et omslag i dansk politik. Og modsætningsvis rummede den indirekte en forsikring til den slesvig-holstenske landsregering om, at der ikke var nogen risiko ved at sikre det danske mindretals rettigheder.

\section{NOTER}

1. Rigsarkivet (RA), Aage Friis' arkiv, notits 16.11.1948.

2. RA, Aage Friis' arkiv, til grev Reventlow 24.11.1948.

3. Grænsevagten 1949 s. 76 , Knud Kristensens erklæring.

4. Grænsevagten 1949 s. 66ff, diverse kommentarer til Knud Kristensens mandatnedlæggelse.

5. RA, la Cours arkiv, fra Knud Kristensen 31.1. med svar 2.2. og gensvar modtaget 4.2.1949.

6. Gransevagten 1949 s. 55.

7. Grænsevagten 1949 s. 118f, tale i VU-Asnæs 15.1. og s. 118, tale i Århus 5.2.1949.

8. Grænsevagten 1949 s. 66, Edvard Sørensens kommentar.

9. RA, Venstres arkiv, rigsdagsgruppens protokol 20.1., 26.1. og 17.2. 1949.

10. Public Record Office, Foreign Office (FO) 371/76529/C1169, C1209, C1231, C1978 og 76530/ C2388, diverse telegrammer, koncepter og notater til Savorys spørgsmål. 
11. Sydslesvigsk Udvalgs arkiv, særlig korrespondance 1947-49, Hans Magle.

12. RA, Venstres arkiv, rigsdagsgruppens protokol 2.3.1949.

13. RA, Det konservative Folkepartis arkiv, rigsdagsgruppens forhandlingsprotokol 4.3. og 21.3.1949.

14. RA, Det radikale Venstres arkiv, rigsdagsgruppens protokol.

15. RA, Venstres arkiv, rigsdagsgruppens protokol 31.1. og 1.4.1949.

16. RA, Venstres arkiv, landsrådsprotokol 8.4.1949.

17. RA, Venstres arkiv, rigsdagsgruppens protokol 6.4.1949. Jf. RA, Det radikale Venstres arkiv, rigsdagsgruppens protokol 4.4. og Folketingets arkiv, Socialdemokratiets gruppeprotokol 5.4.

18. RA, Det radikale Venstres arkiv, rigsdagsgruppens protokol 8.4.1949, kl. 21.20.

19. Rigsdagstidende 1948-49, Folketingets forhandlinger sp. $4995 \mathrm{ff}$.

20. Grænsevagten 1949 s. 213.

21. Grænsevagten 1949 s. 213 f.

22. Rigsdagstidende 1948-49. Folketingets forhandlinger sp. 4740ff (3. behandling af tillægsbevillingsloven), særlig sp. 4753f (Erik Eriksen), sp. $4766 \mathrm{fr}$ (Kraft), sp. 4788 (Dahlgaard), sp. 4815 (Starcke), sp. 4832 (Thorkil Kristensen) og sp. 4857 (Hedtoft).

23. FO 371/76531/C3223, indberetning 13.4.1949.

24. Grænsevagten 1949 s. 242ff, Jf. Dansk Generalsekretariat (DGS), SSF 84.03, resolution fra Sydslesvigsk Udvalgs landsmøde 23-24.4.1949.

25. FO 371/76531/C3922, FO tg til Berlin 9.5.1949.

26. Udenrigsministeriet: Aktstykker vedrørende det sydslesvigske spørgsmål bd. 3, Kbh. 1950, s. $378 \mathrm{ff}$, s. $422 \mathrm{ff}$, s. $453 \mathrm{ff}$ og s. 459.

27. Udenrigsministeriets arkiv (UM) 7Y45a IV, Kauffmann til Brun 25.7.1949, jf. Aktstykker bd. 3, s. 461ff, anmærkningerne til Kauffmanns note af 27.6.1949.

28. Jf. Græensevagten 1949 s. 248 f.

29. UM 3E92, nævnsreferat.

30. RA, Det radikale Venstres arkiv, rigsdagsgruppens forhandlingsprotokol 16.5.1949.

31. RA, Det radikale Venstres arkiv, rigsdagsgruppens protokol.

32. RA, Det konservative Folkepartis arkiv, rigsdagsgruppens protokol.

33. Sydsiesvigsk Udvalgs arkiv, forretningsudvalgets protokol 1946-1949 og DGS, SSF 84.03, Hansen Larsens udkast til støtteerklaring 5.6.1949.

34. Sydslesvig i dag s. 692 .

35. RA, GF 276, hovedstyrelsesprotokol 26.5.1949.

36. UM 7Y112.

37. RA, Holger Andersens arkiv, til Thorkil Kristensen 15.5.1949 og RA, Det konservative Folkepartis arkiv, rigsdagsgruppens protokol 18.5., hvor Aksel Møller ville have sydslesvigerne op.

38. DGS, SSF $84.03,15.6 .1949$.

39. Aktstykker bd. 3, s. 398ff efter Socialdemokraten 21. maj 1949.

40. Grænsevagten 1949 s. 251 f.

41. Jf. Arbejderbevægelsens arkiv og bibliotek, Hans Hedtofts arkiv 47/5, notat 31.5.1949.

42. UM 3E92, nævnsreferat 1.6.1949.

43. Grænsevagten 1949 s. 392.

44. RA, Venstres arkiv, rigsdagsgruppens protokol 2.6.1949.

45. Grænsevagten 1949 s. 293.

46. RA, Det radikale Venstres arkiv, rigsdagsgruppens protokol 4.6.1949.

47. Folketingets arkiv, Socialdemokratiets gruppeprotokol 4.6.1949.

48. UM 3E92, næunsreferat 9.6.1949.

49. RA, Venstres arkiv, rigsdagsgruppens protokol 10.6.1949.

50. UM 7Y47c, udkast af 20.6. efter forste udkast af Troels Fink 13.6.1949.

51. Folketingets arkiv, Socialdemokratiets gruppeprotokol 21.6.1949.

52. Ibid. 23.6.1949.

53. RA, Venstres arkiv, rigsdagsgruppens protokol 10.6., 22.6. og 24.6.1949.

54. RA, Venstres arkiv, landsrådsprotokol. 
55. RA, Venstres arkiv, rigsdagsgruppens protokol 28.6.1949.

56. UM 7Y47c, »Uforbindende udkast« 24.6 .1949 med Gustav Rasmussen til forhandlingsudvalget s.d.

57. Folketingets arkiv, Socialdemokratiets gruppeprotokol 29.6.1949, Gustav Pedersens redegørelse.

58. UM 7 Y 47c.

59. Ibid.

60. RA, Venstres arkiv, rigsdagsgruppens forhandlingsprotokol $29.6 . \mathrm{kl} .9$.

61. Folketingets arkiv, Socialdemokratiets gruppeprotokol $29.6 .1949 \mathrm{kl}$. 16.40.

62. RA, Venstres arkiv, rigsdagsgruppens protokol $29.9 .1949 \mathrm{kl} .16 .15$

63. Folketingets arkiv, Socialdemokratiets gruppeprotokol $29.6 .1949 \mathrm{kl} .18$.

64. Folketingets arkiv, Socialdemokratiets gruppeprotokol 29.6. efter kl. 23.20.

65. RA, Venstres arkiv, rigsdagsgruppens protokol 29.6.1949 efter kl. 23.20.

66. Aktstykker bd. 3, s. 466f, jf. den underskrevne erklæring med tidligere regeringsudkast i UM $7 \mathrm{Y} 47 \mathrm{c}$.

67. Aktstykker bd. 3, s. 469ff, instruks af 6.7 .1949 med efterfolgende indberetninger. 